\title{
Seroprevalence of pertussis antibodies in 6-17-year-old students in Ahvaz, south-west Islamic Republic of Iran
}

\author{
A. Shamsizadeh, ${ }^{1,2}$ R. Nikfar, ${ }^{1}$ H. Yusefi, ${ }^{2}$ E. Abbasi-Montazeri ${ }^{3}$ and B. Cheraghian ${ }^{4}$
}

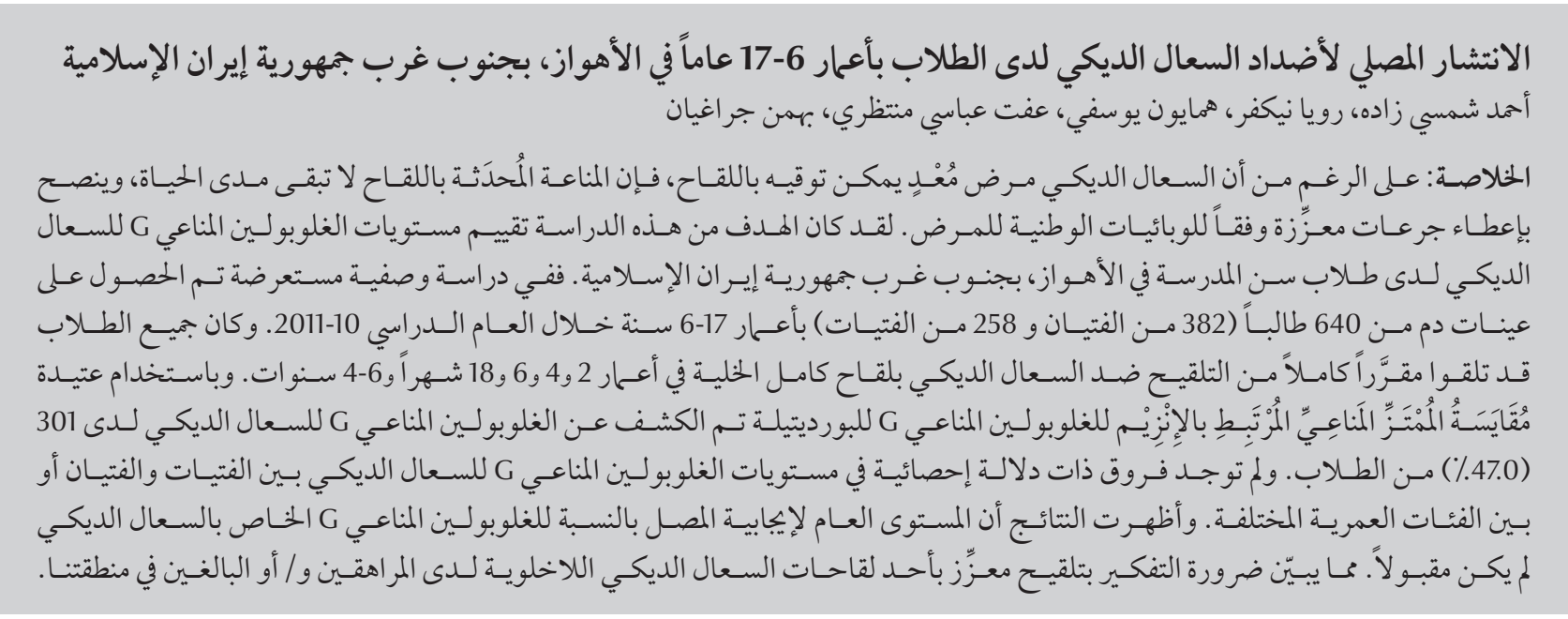

ABSTRACT Although pertussis is a vaccine-preventable infection, vaccine-induced immunity is not lifelong and booster doses are recommended according to national disease epidemiology. The aim of this study was to evaluate pertussis-IgG levels in school-aged students in Ahvaz, south-west Islamic Republic of Iran. In a descriptive, crosssectional study, blood samples were obtained from 640 students (382 boys and 258 girls) aged 6-17 years during 2010-2011. All students had received a full course of pertussis whole-cell vaccination at ages 2, 4, 6 and 18 months and 4-6 years. Using a Bordetella IgG ELISA kit, pertussis-IgG was detected in 301 (47.0\%) students. No statistically significant differences in pertussis-IgG levels were found between girls and boys or across different age groups. The findings show that the overall level of pertussis-IgG seropositivity was unacceptable. Booster vaccination with an acellular pertussis vaccine should be considered in adolescents and/or adults in our region.

Séroprévalence des anticorps de la coqueluche chez des écoliers âgés de 6 à 17 ans à Ahvaz (sud-ouest de la République islamique d'Iran)

RÉSUMÉ Si la coqueluche est une infection évitable par la vaccination, l'immunité induite par le vaccin ne dure pas toute la vie et des doses de rappel sont recommandées en fonction de l'épidémiologie de la maladie dans le pays. L'objectif de la présente étude était d'évaluer les taux d'IgG anticoquelucheux chez des écoliers à Ahvaz (sud-ouest de la République islamique d'Iran). Dans une étude transversale descriptive, des échantillons de sang ont été prélevés chez 640 écoliers (382 garçons et 258 filles) âgés de 6 à 17 ans en 2010 et 2011 . Tous les écoliers avaient reçu un cycle complet du vaccin anticoquelucheux à germes entiers à l'âge de 2, 4, 6 et 18 mois puis à 4-6 ans. À l'aide du kit ELISA spécialisé, des IgG anti-Bordetella pertussis ont été dépistés chez 301 écoliers, soit 47,0 \%. Aucune différence statistiquement significative n'a été observée entre les taux d'IgG anticoquelucheux des filles et des garçons ou entre les différents groupes d'âges. Ces résultats révèlent que le taux global de séropositivité aux IgG anticoquelucheux est inacceptable. Une vaccination de rappel au moyen d'un vaccin anticoquelucheux acellulaire doit être envisagée chez les adolescents et/ou les adultes de notre région.

'Health Research Institute, Infectious and Tropical Diseases Research Centre; ${ }^{2}$ Aboozar Children's Hospital; ${ }^{3}$ Department of Microbiology, Faculty of Medicine; ${ }^{4}$ Department of Epidemiology, Faculty of Health; Ahvaz Jundishapur University of Medical Sciences, Ahvaz, Islamic Republic of Iran (Correspondence to A. Shamsizadeh: shamsizadeh@ajums.ac.ir, shamsizadeh-a@hotmail.com).

Received: 22/07/13; accepted: 07/05/14 


\section{Introduction}

Pertussis or whooping cough is a highly contagious, vaccine-preventable respiratory disease caused by Bordetella pertussis and less frequently by B. parapertussis. The illness occurs worldwide and affects all age groups (1). National immunization programmes against pertussis, which were introduced in many countries in the mid-1950s, have dramatically decreased the incidence and complications of pertussis in children (2). Despite universal pertussis vaccination in many countries, the circulation of B. pertussis has not been eliminated. There are reports from a large number of countries that the incidence of pertussis is increasing in adolescents and adults due to waning immunity (3-7). These patients are a source of infection for infants and young children (3).

Several explanations has been proposed for the re-emergence of pertussis in vaccinated children, including poor vaccine quality, improved diagnostic facilities, increased awareness of the disease and waning of vaccine-induced immunity $(4,8)$. The immunity following vaccination is not lifelong and it gradually decreases over $10-12$ years (9). Booster vaccination by an acellular vaccine has been recommended in some countries such as France, Germany and Canada. In 2006, the American Academy of Paediatrics published their recommendations for pertussis booster vaccination (10).

Immunization by the triple diphtheria, tetanus and whole-cell pertussis vaccine has been applied in the Islamic Republic of Iran since the 1950s $(11,12)$. The vaccine is administered at the 2nd, 4th and 6th months of life, with booster doses at 18 months and between 4-6 years of age. Since recommendations for pertussis booster vaccination depend on the national disease epidemiology, we aimed to determine the seroprevalence of pertussis antibodies among school-aged children. The prevalence of pertussis antibody in different age groups has not been adequately studied in the Islamic Republic of Iran and the results of this study, together with future studies in other parts of the country, could help to inform policy decisions about pertussis booster vaccination.

\section{Methods}

\section{Study design}

In a descriptive, cross-sectional study blood samples were obtained from primary-school, junior high-school and high-school students aged 6-17 years in Ahvaz, south-west Islamic Republic of Iran from October 2010 to June 2011.

\section{Sampling}

We used the following sample size determination formula for estimating a proportion to calculate the required sample size, in which $a=0.05, P=0.7$ (based on previous studies), $d=0.05$ and design effect $=1.93$ were considered. Finally, a sample of 623 students was estimated for the survey.

A multi-stage, stratified, cluster sampling design was used, in which at the first stage we classified all schools in 6 strata by sex of students and type of schools. Then, proportionally to size, 18 schools were randomly selected as the clusters. At the next stage, using simple random sampling, $1 / 3$ of classes in each chosen school were selected. Finally, using systematic random sampling, $1 / 6$ of students in each chosen classroom were selected for the study. Students with a history of chronic cough or evidence of acute respiratory tract infection were excluded from the study.

Before sampling, written informed consent was obtained from the students' parents. The study was approved by the ethics committee of Ahvaz Jundishapur University of Medical Sciences.

\section{Data collection}

All students had received a full course of pertussis whole-cell vaccination (Razi
Institute of Iran) at the ages of 2, 4, 6 and 18 months and $4-6$ years. Confirmation of vaccination history was done by observation of each student's vaccination card. The clinical information was collected using a questionnaire to students' parents for young children or by the students themselves in high school.

For the serological study, a venous blood sample of 3-5 $\mathrm{mL}$ was drawn from each child, centrifuged and stored at $-20{ }^{\circ} \mathrm{C}$ until assayed. Immunoglobulin $\mathrm{G}(\mathrm{Ig} G)$ antibodies against a mixture of B. pertussis antigens (endotoxin, filamentous haemagglutinin and pertussis toxin) were measured using a commercially available enzyme-linked immunosorbent assay kit (IBL International $\mathrm{GmbH}$ ).

According to the manufacturer's instructions for qualitative evaluation, the cut-off index was calculated from the mean optical densities (OD) of the sample and cut-off value. Samples with an OD within a range of $20 \%$ around the cut-off value (grey zone) are considered as borderline, samples with higher ODs are positive and samples with lower ODs are negative. Antibody levels $>24$ $\mathrm{U} / \mathrm{mL}$ were considered as positive, $<16$ $\mathrm{U} / \mathrm{mL}$ as negative and $16-24 \mathrm{U} / \mathrm{mL}$ as equivocal. Equivocal samples were rechecked and classified as positive or negative. Antibody levels are shown as geometric mean titres (GMTs).

\section{Data analysis}

The data were analysed using SPSS software, version 18.00. The chi-squared and Fisher exact tests were used for analysis. $P<0.05$ was considered as statistically significant.

\section{Results}

Out of a total of 640 students, 258 (40.3\%) were girls and 382 (59.7\%) boys. The mean age of students was 12.1 (standard deviation 3.18) years, range 6-17 years. The participants 


\begin{tabular}{|c|c|c|c|c|c|c|}
\hline \multirow[t]{3}{*}{ Variable } & \multirow{3}{*}{$\begin{array}{l}\text { Total } \\
\text { No. }\end{array}$} & \multicolumn{5}{|c|}{ Pertussis antibody levels } \\
\hline & & \multicolumn{2}{|c|}{$>24 \mathrm{U} / \mathrm{mL}$ Positive } & \multicolumn{2}{|c|}{$<16 \mathrm{U} / \mathrm{mL}$ Negative } & \multirow{2}{*}{$\begin{array}{c}\text { Geometric mean titre } \\
(\mathrm{U} / \mathrm{mL})\end{array}$} \\
\hline & & No. & $\%$ & No. & $\%$ & \\
\hline Total & 640 & 301 & 47.0 & 339 & 53.0 & 25.0 \\
\hline \multicolumn{7}{|l|}{ Sex } \\
\hline Boys & 382 & 173 & 45.3 & 209 & 54.7 & 26.0 \\
\hline Girls & 258 & 128 & 49.6 & 130 & 50.4 & 23.6 \\
\hline \multicolumn{7}{|c|}{ Age group (years) } \\
\hline $6-11$ & 280 & 132 & 47.1 & 148 & 52.9 & 23.8 \\
\hline $12-14$ & 179 & 92 & 51.4 & 87 & 48.6 & 29.3 \\
\hline $15-17$ & 181 & 77 & 42.5 & 104 & 57.5 & 22.4 \\
\hline
\end{tabular}

consisted of 280 (43.8\%) elementaryschool (aged 6-11 years), 179 (28.0\%) junior high-school (aged 12-14 years) and $181(28.2 \%)$ high-school students (aged 16-17 years).

IgG antibodies against $B$. pertussis were detected in 301 (47.0\%) of the 640 samples analysed. The GMT of pertussis antibody in all samples was $25.0 \mathrm{U} / \mathrm{mL}$ (95\% confidence interval: $20.8-29.2 \mathrm{U} / \mathrm{mL}$ ). The GMT of pertussis antibodies in the boys and girls were $26.0 \mathrm{U} / \mathrm{mL}$ and $23.6 \mathrm{U} / \mathrm{mL}$ respectively $(P=0.45)$ (Table 1$)$. Table 1 also shows the frequency of pertussis antibodies by age group. The level of pertussis antibodies did not show a statistically significant difference between the different age groups $(P=0.22)$.

\section{Discussion}

We documented a $47.0 \%$ seroprevalence of pertussis antibodies in students aged 6-17 years. The levels of pertussis antibodies did not change significantly across the different age groups Others studies from the Islamic Republic of Iran showed a pertussis seroprevalence of $60.6 \%$ in military recruits (12) and $47.6 \%$ in first-year medical students (13).

Pertussis antibodies were detected in $47.1 \%$ of the primary-school students (6-11 years). Since these students had received the second booster dose of pertussis vaccine when they were 4-6 years old, the levels of pertussis antibodies were lower than expected. In one study from Turkey, $48.3 \%$ of children aged 4-6 years were positive for pertussis antibodies (5), but in most studies, including another study from the Islamic Republic of Iran, children in this age group had higher levels of pertussis antibodies $(11,14-16)$. Possible reasons for low levels of pertussis antibodies in a relatively short period after vaccination include the quality of vaccine, lack of cold-chain preservation and poor vaccine administration technique.

In our study , 51.4\% of high-school students were susceptible to pertussis. Because of waning of pertussis antibodies after vaccination $(6,7,17,18)$, we expected that the antibody level would be much lower in high-school students compared with younger students. The similar antibody level in both age groups indicates the presence of natural infection in the community, which increased the antibody levels in high-school students.

Similar to most studies, we found no significant difference in the level of pertussis antibodies between boys and girls $(17,19)$. However in one study girls had higher antibody levels than boys; however, the authors did not discuss any reasons for this difference (9).

One limitation of our study was the use of a mixture of pertussis antigens.
This may cross-react with antibodies produced by other bacteria present in the sera.

\section{Conclusions}

A significant portion of school-aged children in this area of the Islamic Republic of Iran were susceptible to pertussis. In addition to a reassessment of vaccination in 4-6 year-old children, a booster dose of an acellular pertussis vaccine in adolescents and/or adults is recommended (20,21). Further studies are needed to evaluate the levels of pertussis antibodies in different age groups in other parts of the country to plan a national programme for pertussis booster vaccination.

\section{Acknowledgements}

This paper comprised part of the thesis of Homayon Yosefi, and financial support was provided by Ahvaz Jundishapur University of Medical Sciences. We thank all the participating students and their families. We also thank Mrs Shohreh Banidavoodi for preparation of the manuscript.

Funding: This study was supported by the Infectious and Tropical Diseases Research Center of Ahvaz Jundishapur University of Medical Sciences.

Competing interests: None declared. 
1. Cherry JD, Heininger U. Pertussis and other Bordetella infections. In: Feigin RD, Cherry JD, Demler-Harrison GL, Kaplan $\mathrm{SL}$, editors. Feigin and Cherry's textbook of pediatric infectious diseases. 6th ed. Philadelphia: Saunders-Elsevier; 2009. pp. 1683-706.

2. Wilder-Smith A, Ng S, Earnest A. Seroepidemiology of pertussis in the adult population of Singapore. Ann Acad Med Singapore. 2006 Nov;35(11):780-2. PMID:17160193

3. Vatansever U, Cöplü N, Oner N, Sönmez C, Karasalihoglu S, Kurtoglu D, et al. Seroprevalance of Bordetella pertussis antibodies among healthy adolescent girls in Edirne. Swiss Med Wkly. 2005 Sep 3;135(35-36):531-6. PMID:16323071

4. De Greeff SC, de Melker HE, van Gageldonk PG, Schellekens JF, van der Klis FR, Mollema L, et al. Seroprevalence of pertussis in The Netherlands: evidence for increased circulation of Bordetella pertussis. PLoS One. 2010;5(12):e14183. PMID:21152071

5. Cevik M, Beyazova U, Aral AL, Duyan Camurdan A, Ozkan S, Sahin F, et al. Seroprevalence of IgG antibodies against Bordetella pertussis in healthy individuals aged 4-24 years in Turkey. Clin Microbiol Infect. 2008 Apr;14(4):388-90. PMID:18190581

6. Dilli D, Bostanci I, Dallar Y, Buzgan T, Irmak H, Torunoğlu MA. Recent findings on pertussis epidemiology in Turkey. Eur J Clin Microbiol Infect Dis. 2008 May;27(5):335-41. PMID:18193304

7. Hellenbrand W, Beier D, Jensen E, Littmann M, Meyer C, Oppermann $\mathrm{H}$, et al. The epidemiology of pertussis in Germany: past and present. BMC Infect Dis. 2009;9:22. PMID:19243604

8. 8. Seyed MA, Said F. Bukhari SHA. Seroepidemiology of Bordetella pertussis infections in the twin cities of Pakistan. North Am J Med Sci. 2009;1:353-5.

9. Arav-Boger R, Ashkenazi S, Gdalevich M, Cohen D, Danon YL. Seroprevalence of pertussis antibodies among adolescents in Israel. Isr Med Assoc J. 2000 Feb;2(2):174-7. PMID:10804947

10. Broder KR, Cortese MM, Iskander JK, Kretsinger K, Slade $\mathrm{BA}$, Brown $\mathrm{KH}$, et al.; Advisory Committee on Immunization Practices (ACIP). Preventing tetanus, diphtheria, and pertussis among adolescents: use of tetanus toxoid, reduced diphtheria toxoid and acellular pertussis vaccines recommendations of the Advisory Committee on Immunization Practices (ACIP). MMWR Recomm Rep. 2006 Mar 24;55 RR3:1-34. PMID:16557217

11. Zarei S, Jeddi-Tehrani M, Akhondi MM, Zeraati $H$, Kheirkhah $\mathrm{T}$, Ghazanfari $M$, et al. Immunogenicity of a triple diphtheriatetanus-whole cell pertussis vaccine in Iranian preschool children. Iran J Immunol. 2007 Jun;4(2):101-9. PMID:17652850
12. Izadi M, Afsharpaiman S, Jonaidi Jafari N, Ranjbar R, Gooya MM, Robat Sarpooshi J, et al. Immunization status of Iranian military recruits against Bordetella pertussis infection (whooping cough). J Infect Dev Ctries. 2011 Mar;5(3):224-6. PMID:21444992

13. Hashemi SH, Ranjbar M, Hajilooi M, Seif-Rabiei MA, Bolandi M, Moghimi J. Seroprevalence of Immunoglobulin G antibodies against pertussis toxin among asymptomatic medical students in the west of Iran: a cross sectional study. BMC Infect Dis. 2009;9:58. PMID:19426546

14. Blennow M, Granström M. Long term serologic follow-up after pertussis immunization. Pediatr Infect Dis J. 1990 Jan;9(1):21-6. PMID:2300411

15. Annunziato PW, Rothstein EP, Bernstein HH, Blatter MM, Reisinger KS, Pichichero ME. Comparison of a three-component acellular pertussis vaccine with a whole-cell pertussis vaccine in 4- through 6-year-old children. Elmwood Pediatric Associates, Pennridge Pediatric Associates. Arch Pediatr Adolesc Med. 1994 May;148(5):503-7. PMID:8180641

16. Esen B, Coplu N, Kurtoglu D, Gozalan A, Akin L. Prevalence of high antibody titers of pertussis in Turkey: reflection of circulating microorganism and a threat to infants. J Clin Lab Anal. 2007;21(3):154-61. PMID:17506474

17. Duranoglu L, Sönmez C, Vurucu S, Kurtoglu D, Kesik V, Coplu $\mathrm{N}$, et al. Evaluation of pertussis immunity status in schoolchildren immunized with whole-cell vaccine. Epidemiol Infect. 2010 Feb;138(2):299-303. PMID:19580694

18. Grimprel E, Bégué $\mathrm{P}$, Anjak I, Njamkepo E, François P, Guiso N. Long-term human serum antibody responses after immunization with whole-cell pertussis vaccine in France. Clin Diagn Lab Immunol. 1996 Jan;3(1):93-7. PMID:8770511

19. Socan M, Prosenc K, Vegnuti M. Seroprevalence of IgG antibodies to pertussis toxin in the Slovene population. Wien Klin Wochenschr. 2006 Jun;118(11-12):336-40. PMID:16855922

20. Hallander HO, Andersson M, Gustafsson L, Ljungman M, Netterlid E. Seroprevalence of pertussis antitoxin (anti-PT) in Sweden before and 10 years after the introduction of a universal childhood pertussis vaccination program. APMIS. 2009 Dec;117(12):912-22. PMID:20078557

21. Domínguez A, Vidal J, Plans P, Salleras L. The seroepidemiology of B. pertussis infection in Catalonia, Spain. Epidemiol Infect. 2001 Apr;126(2):205-10. PMID:11349970 